\title{
Efficacy of 4-hour rescue therapeutic plasma exchange in severe septic shock patients
}

\author{
RABAB MAHMOUD AHMED ${ }^{1}$, AMIN R. SOLIMAN $^{1}$, AHMAD YOUSRY $^{2}$, KHALED MARZOUK $^{1}$, FAROUK FARIS $^{3}$ \\ ${ }^{1}$ Department of Internal Medicine, Faculty of Medicine, Cairo University, Cairo, Egypt \\ ${ }^{2}$ Department of Cardiology, Faculty of Medicine, Zagazig University, Cairo, Egypt \\ ${ }^{3}$ Department of Critical Care, Faculty of Medicine, Cairo University, Cairo, Egypt
}

\begin{abstract}
Background. Early intervention for septic shock is crucial to reduce mortality and improve outcome. There is still a great debate over the exact time of therapeutic plasma exchange (TPE) administration in septic shock patients. This study aims to investigate the effect of early initiation (within 4 hours) of TPE in severe septic shock on hemodynamics \& outcome.

Methods. We conducted a prospective, before-after case series study on 16 septic shock patients requiring high doses of vasopressors admitted in two ICUs from Cairo, Egypt. All of our patients received TPE within 4 hours of ICU admission. The fresh frozen plasma exchange volume $=1.5 \times$ plasma volume.

Results. In the 16 patients included in the study, mean arterial pressure was significantly improved after the initial TPE $(\mathrm{p}<0.002)$ and norepinephrine dose which significantly reduced post TPE $(p<0.001)$. In addition, norepinephrine dose to mean arterial pressure significantly improved $(p<0.001)$. There was reduction of a net 6 hours fluid balances following the first TPE were observed in all the patients $(\mathrm{p}<0.03)$ by a mean of $757 \mathrm{ml}$. Systemic vascular resistance index was markedly improved post-TPE along with statistically improved cardiac index $(p<0.01)$. Stroke volume variance was also significantly decreased after the TPE sessions $(\mathrm{p}<0.01)$. C-reactive protein significantly improved after TPE $(\mathrm{P}<0.01)$.

Conclusion. Early initiation of TPE in severe septic shock patients might improve hemodynamic
\end{abstract} measures.

Key words: septic shock, plasma exchange, hemodynamics, norepinephrine, critical care.

\section{INTRODUCTION}

Sepsis is a life threatening dysregulated host response to infection. Given the injurious role of the overwhelming immune response and the consumption of protective plasmatic factors such as ADAMTS13 (a disintegrin and metalloproteinase with a thrombospondin type 1 motif, member 13), it was hypothesized that early therapeutic plasma exchange (TPE) in severely ill individuals might be beneficial as it combines two aspects in one procedure; removal of harmful circulating molecules as well as replacement of protective plasma protein [1].

Latest septic shock guidelines in 2016 clarify that further studies are needed to determine the clinical benefit of TPE as the present trials are small, unblended, with high-risk of bias and unclear patient selection [2].

The exact time of the administration of TPE in reduction of septic shock mortality is uncertain in different studies available regarding this issue [3-9].

Septic shock is considered a medical emergency. Early identification with appropriate immediate intervention in the initial hours definitely improves the outcomes [10-16]. The guidelines announced that these complex patients need urgent rapid treatment, besides attaining more precise measurements of hemodynamic status from them [17-22].
This study aims to investigate the effect of early initiation (within 4 hours) of TPE in septic shock on hemodynamics and outcome.

\section{MATERIAL AND METHODS}

This study is a prospective observational study conducted at two general intensive care units of Cairo University Hospitals from July 2018 to January 2019. It is approved by the Ethical and Research Committee of the National Research Centre.

\section{Inclusion criteria}

Sixteen patients with severe septic shock with an onset $<12$ hours requiring high doses of noradrenaline $(>0.6 \mathrm{mcg} / \mathrm{kg} / \mathrm{min}$ ) were included in the study.

Sepsis is now defined as life-threatening organ dysfunction caused by a dysregulated host response to infection. Septic shock is a subset of sepsis with circulatory and cellular/metabolic dysfunction associated with a higher risk of mortality [23].

All of our patients were subjected to recording the conventional clinical and chemical data. All patients received septic shock management according to recent sepsis guidelines treatment in addition to TPE within 4 hours of ICU admission. 
Continuous hemodynamic monitoring was done using the cardiothoracic impedance (ICON), OSYPKA Medical, Cardiotronic.

\section{Exclusion criteria}

Patients who need renal replacement therapy.

\section{TPE procedure}

A median of two TPE therapies (with a range 1-3) were performed for each patient according to the clinical situation.

Fresh frozen plasma exchange volume: $1.5 \times$ plasma volume. Estimated plasma volume (in liters $)=0.07 \times$ weight $(\mathrm{kg}) \times(1$-hematocrit $)$. Heparin was used for anticoagulation. Membrane technique was used in all patients. We used membrane Gambro PF 2000 (polypropylene, $0.4 \mathrm{~m}^{2}$; Gambro, Hechingen, Germany). Anti-histamines were given as pre-treatment medications. TPE sessions were stopped if progressive hemodynamic instability had occured.

\section{Statistical analysis}

Numerical variables are presented as mean \pm $\mathrm{SD}$, and categorical variables as frequencies and percentages. For the comparison between the two independent groups, the Chi-squared test or Fischer's exact test were used to compare percentages between different groups of patients. Numerical data were tested for normality by the Shapiro-Wilk normality test. Normally distributed data were analyzed using independent samples T-test. Data found to be nonnormally distributed were analyzed using the MannWhitney U test. Paired samples were compared using the paired-samples T-test or the Wilcoxon signed-rank test as appropriate. Data analysis was done using Statistics/Data Analysis (STATA) version 13.1 software.

\section{RESULTS}

Demographic and some laboratory data of our 16 patients are shown in Table 1.

Table 1

Demographic data of studied population (Total 16 patients)

\begin{tabular}{|c|c|}
\hline & Number/\% \\
\hline Age & $56 \pm 4.5 y$ \\
\hline \multicolumn{2}{|l|}{ Sex } \\
\hline Male & $10(62.5 \%)$ \\
\hline Female & $6(37.5 \%)$ \\
\hline \multicolumn{2}{|l|}{ Chronic disease } \\
\hline$D M$ & $12(75 \%)$ \\
\hline HTN & $10(62.5 \%)$ \\
\hline$C K D$ & $9(56.25 \%)$ \\
\hline$C L D$ & $3(18.75)$ \\
\hline Malignancy & $1(6.25 \%)$ \\
\hline \multicolumn{2}{|l|}{ Source of sepsis } \\
\hline Surgical site & $6(37.5 \%)$ \\
\hline Pneumonia & $3(18.75)$ \\
\hline Intra-abdominal & $5(31.25)$ \\
\hline UTI & $2(12.5 \%)$ \\
\hline \multicolumn{2}{|l|}{ Lab results } \\
\hline$T L C$ mean $\pm \mathrm{SD}$ & $21.4 \pm 3.6$ \\
\hline $\begin{array}{l}\text { Platelet count (range) } \\
\quad 1 \text { day before initiation of first TPE }\end{array}$ & $\begin{array}{c}\text { Mean } \mathbf{7 8 , 0 0 0} \\
\text { Range }(\mathbf{4 5 , 0 0 0 - 1 4 0 , 0 0 0 )}\end{array}$ \\
\hline 1 day after first TPE & $\begin{array}{c}\text { Mean 63,000 } \\
\text { Range }(50,000-160,000)\end{array}$ \\
\hline \multicolumn{2}{|l|}{ Culture results } \\
\hline Gram -ve organisms & $16(100 \%)$ \\
\hline Gram +ve organisms & $6(37.5 \%)$ \\
\hline Fungal organisms & 3 \\
\hline APACHE score & $36.6 \pm 4.2$ \\
\hline MV duration (days) & $4 \pm 2$ \\
\hline ICU stay (days) & $7 \pm 4$ \\
\hline Mortality & $10(62.5 \%)$ \\
\hline
\end{tabular}

$D M=$ Diabetes mellitus; $H T N=$ Hypertension $; C K D=$ chronic kidney disease $; C L D=$ chronic liver disease $;$ UTI $=$ urinary tract infection; $T L C=$ total leucocytes count, $M V=$ mechanical ventilation. 


\section{Clinical data}

Mean arterial pressure was significantly improved after the initial TPE $(\mathrm{p}<0.002)$. Norepinephrine dose was significantly reduced post TPE $(p<0.001)$.
In addition, norepinephrine dose to mean arterial pressure significantly improved, $(\mathrm{p}<0.001)$. There was a reduction of net 6 hours of fluid balances following the first TPE observed in all the patients by a difference of $757 \mathrm{~mL}(\mathrm{p}<0.03)$ (Table 2).

Table 2

Routine clinical shock parameters (Total 16 patients)

\begin{tabular}{|l|c|c|c|}
\hline \multicolumn{1}{|c|}{ Parameter } & Pre - TPE & Post - TPE & p value \\
\hline Mean arterial pressure MAP (mm Hg) & $68.65 \pm 8.19$ & $70.92 \pm 6.33$ & $<\mathbf{0 . 0 0 2}$ \\
\hline Norepinephrine dose (NE) $\boldsymbol{\mu g} / \mathbf{k g} / \mathbf{m i n}$ & $0.72 \pm 0.08$ & $0.51 \pm 0.10$ & $<\mathbf{0 . 0 0 1}$ \\
\hline MAP/NE dose ratio & $86 \pm 43$ & $109 \pm 47$ & $<\mathbf{0 . 0 0 1}$ \\
\hline 6 hours fluid balance (ml) & $2720 \pm 2518$ & $1963 \pm 1805$ & $<\mathbf{0 . 0 3}$ \\
\hline
\end{tabular}

MAP $=$ Mean arterial pressure.

CRP was significantly improved after TPE $(p<0.01)$. Minor changes in the oxygenation index with non-significant results. Lactate mildly increased post-TPE sessions but also this was insignificant (Table 3).

\section{Hemodynamic measures}

Systemic vascular resistance index, a surrogate of afterload was markedly improved post-TPE along with statistically improved cardiac index, $\mathrm{p}<0.01$. Stroke volume variance also was significantly decreased after the TPE sessions, $\mathrm{p}<0.02$ (Table 4).

\section{Mortality}

Mean APACHE score at inclusion was 36.6 \pm 4 with a predicted mortality of $86.7 \%$. However, the true measured mortality was only $62.5 \%$. The time at which $50 \%$ of patients have died was 7 days from onset of follow up with $95 \%$ CI: $5.40-8.59$ as shown in Table 1 and Figure 1.

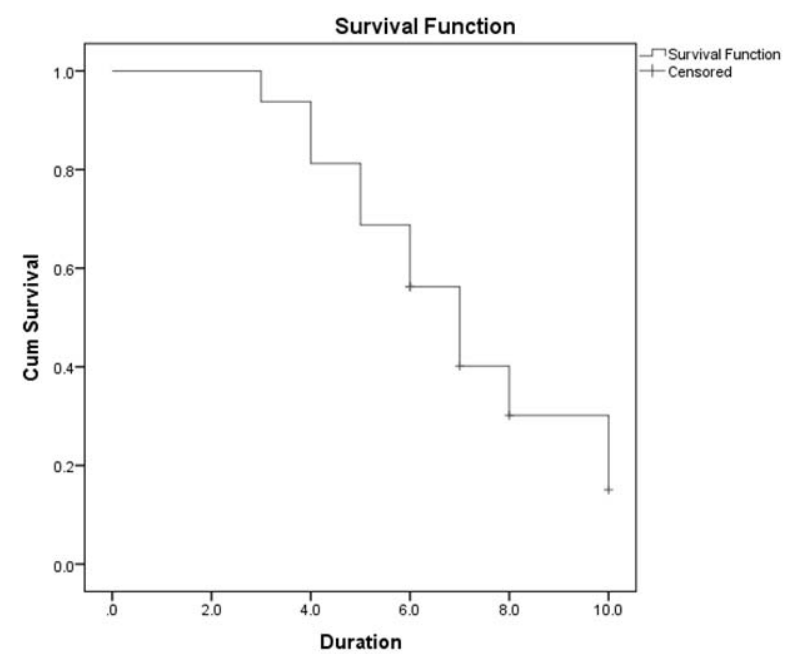

Figure 1. Kaplan Meier curve showing our patients mortality.

Table 3

Biochemical surrogate and oxygenation (Total 16 patients)

\begin{tabular}{|l|c|c|c|}
\hline \multicolumn{1}{|c|}{ Parameter } & Pre - TPE & Post - TPE & p value \\
\hline C-reactive protein CRP mg/l & $205 \pm 101$ & $102 \pm 65$ & $<0.01$ \\
\hline Lactate mmol/l & $6.7 \pm 3.6$ & $7.4 \pm 2.8$ & NS \\
\hline Oxygenation index $\mathbf{P a O}_{\mathbf{2}} / \mathbf{F i O}_{\mathbf{2}}$ & $110 \pm 50.5$ & $109 \pm 49.2$ & NS \\
\hline
\end{tabular}

Table 4

Hemodynamic monitoring parameters (Total 16 patients)

\begin{tabular}{|l|c|c|c|}
\hline \multicolumn{1}{|c|}{ Parameter } & Pre - TPE & Post - TPE & p value \\
\hline Systemic vascular resistance index (SVRI) & $1355 \pm 396$ & $1506 \pm 611$ & $<\mathbf{0 . 0 1}$ \\
\hline Stroke volume variance (SVV) & $16.7 \pm 12.4$ & $7.95 \pm 6.52$ & $<\mathbf{0 . 0 2}$ \\
\hline Cardiac index (CI) & $2.7 \pm 1.2$ & $3.4 \pm 101$ & $<\mathbf{0 . 0 1}$ \\
\hline
\end{tabular}

\section{DISCUSSION}

Despite adequate antibiotics administration, the gold standard treatment and the most powerful management strategy for septic shock as recommended by numerous guidelines, the estimated prevalence of mortality in those patients reach up to $70 \%$ [10]. In this line of concept, the need for searching for other interventions and treatment modalities aside from antibiotic therapy is urgently needed in a trial 
to overcome the high mortality rate for a common disease. Such disease represents a significant clinical and economic problem in ICU, particularly in the early phase of sepsis during the period of cytokines over-production. [3].

Improving coagulation, hemodynamics and replenishment of useful factors is a good rationale for the use of (TPE) [4] as suggested in some small trails. However, the optimum timing of administration of TPE is still debatable and studies on TPE after 24 hours of ICU admission demonstrated no significant reduction of mortality [5, 24].

We aim in this study to determine whether application of very early TPE within 4 hours of ICU admission can improve or not septic shock haemodynamic parameters, which are prognostically important in those patients.

The key finding of this study is that septic shock parameters are significantly improved in patients treated with very early TPE (within 4 hours) such as the mean arterial pressure, reduction of norepinephrine dose, improvement of norepinephrine dose to mean arterial pressure and the reduction of net 6 hours fluid balances by a mean of $757 \mathrm{ml}$. Moreover, the mortality in our sample was lesser than the mortality predicted by the APACHE score (62.5\%, versus $86.7 \%)$, which could suggest a reduction in mortality, too.

In addition, hemodynamic parameters like Systemic vascular resistance index (a surrogate of afterload) and Stroke volume variance are markedly improved post-TPE along with improved cardiac index.

By literature review, there are some other recent researches between 2000 and 2018 that studied the effect of TPE as a rescue therapy in severe sepsis and septic shock populations. Some of these studies are summarized in Table 5.

Table 5

Recent researches studied TPE in sepsis and septic shock

\begin{tabular}{|c|c|c|c|c|c|c|}
\hline Study & Description & No. of pts & $\begin{array}{c}\text { Populations } \\
\text { studied }\end{array}$ & Main end-points & Timing of TPE & Results \\
\hline \begin{tabular}{|l|} 
Johannes \\
Hadem et al., \\
$2014[9]$
\end{tabular} & $\begin{array}{l}\text { Retrospective } \\
\text { observational } \\
\text { single-centre } \\
\text { study }\end{array}$ & \begin{tabular}{|l|}
23 \\
consecutive \\
patients
\end{tabular} & $\begin{array}{l}\text { Severe sepsis or } \\
\text { septic shock }\end{array}$ & \begin{tabular}{|l|} 
Main surrogate \\
markers of multiple \\
organ failure \\
before, during and \\
after TPE as well \\
as survival rates.
\end{tabular} & $\begin{array}{l}\text { TPEs were performed } 1 \\
\text { day after ICU admission } \\
\text { in } 7 \text { patients and range } \\
\text { from day } 2-26 \text { in the } \\
\text { others. }\end{array}$ & $\begin{array}{l}\text { Data suggest that some } \\
\text { patients with severe sepsis } \\
\text { and septic shock may } \\
\text { experience hemodynamic } \\
\text { stabilisation by early TPE } \\
\text { therapy. }\end{array}$ \\
\hline $\begin{array}{l}\text { Busund R. } \\
\text { et al., 2002 } \\
{[6]}\end{array}$ & $\begin{array}{l}\text { Prospective, } \\
\text { randomised, } \\
\text { study }\end{array}$ & $\begin{array}{l}106 \\
\text { Patients }\end{array}$ & $\begin{array}{l}\text { Severe sepsis or } \\
\text { septic shock }\end{array}$ & $\begin{array}{l}\text { 28-day survival } \\
\text { was the primary } \\
\text { end point. }\end{array}$ & $\begin{array}{l}\text { Immediately after the } \\
\text { diagnosis of severe sepsis } \\
\text { or septic shock, the patients } \\
\text { were randomised to } \\
\text { receive TPE. In addition } \\
\text { to conventional sepsis } \\
\text { treatment or conventional } \\
\text { sepsis treatment alone. } \\
\end{array}$ & Non conclusive \\
\hline $\begin{array}{l}\text { Stegmayr } \\
\text { BG, 2003 [8] }\end{array}$ & $\begin{array}{l}\text { Retrospective } \\
\text { study }\end{array}$ & $\begin{array}{l}76 \\
\text { consective } \\
\text { patients }\end{array}$ & $\begin{array}{l}\text { DIC and MOD } \\
\text { syndrome } \\
\text { Septic shock } \\
\text { was present in } \\
88 \% \text {, while the } \\
\text { others had } \\
\text { another reason } \\
\text { than sepsis for } \\
\text { the MOD } \\
\text { syndrome }\end{array}$ & Survival rates & Not specified & Varying results \\
\hline $\begin{array}{l}\text { Ataman K. 4, } \\
2002[7]\end{array}$ & $\begin{array}{l}\text { Retrospective } \\
\text { observational } \\
\text { study }\end{array}$ & 7 patients & $\begin{array}{l}\text { Six surgical and } \\
\text { one medical with } \\
\text { norepinephrine- } \\
\text { refractory septic } \\
\text { shock }\end{array}$ & $\begin{array}{l}\text { To examine the short- } \\
\text { term cardiovascular } \\
\text { effects of } \\
\text { plasmapheresis, } \\
\text { catecholamine dose, } \\
\text { gas exchange, acid- } \\
\text { base status, diuresis, } \\
\text { C-reactive protein, } \\
\text { white blood cell } \\
\text { count, and Simplified } \\
\text { Acute Physiological } \\
\text { Score II. }\end{array}$ & $\begin{array}{l}\text { As a rescue therapy but } \\
\text { time not specified }\end{array}$ & $\begin{array}{l}\text { No changes in measured } \\
\text { variables were found in } \\
\text { the first } 24 \mathrm{~h} \text { after a TPE. } \\
\text { They recommend that the } \\
\text { procedure needs rigorous } \\
\text { evaluation even as } \\
\text { "rescue therapy" in } \\
\text { patients with septic } \\
\text { shock. }\end{array}$ \\
\hline
\end{tabular}


Continued (Table 5)

\begin{tabular}{|l|l|l|l|l|l|l|}
\hline $\begin{array}{l}\text { Ronco C., } \\
\mathbf{2 0 0 2}[5]\end{array}$ & $\begin{array}{l}\text { Prospective, } \\
\text { pilot, } \\
\text { crossover } \\
\text { clinical trial }\end{array}$ & 10 patients & $\begin{array}{l}\text { Septic shock } \\
\text { combined with } \\
\text { haemodialysis }\end{array}$ & $\begin{array}{l}\text { Mean arterial } \\
\text { pressure, } \\
\text { norepinephrine } \\
\text { requirements, and } \\
\text { leukocyte tumor } \\
\text { necrosis factor- } \\
\text { alpha }\end{array}$ & Not specified & $\begin{array}{l}\text { Improved hemodynamics } \\
\text { were found (Changes } \\
\text { were found in the studied } \\
\text { parameters after 10 hrs of } \\
\text { each treatment). }\end{array}$ \\
\hline $\begin{array}{l}\text { Schmidt J., } \\
\mathbf{2 0 0 0}[4]\end{array}$ & $\begin{array}{l}\text { Observational } \\
\text { pilot study }\end{array}$ & 43 & $\begin{array}{l}\text { Continuous } \\
\text { venovenous } \\
\text { hemofiltration } \\
\text { (CVVHF) } \\
\text { combined with } \\
\text { TPE in sepsis }\end{array}$ & $\begin{array}{l}\text { Arterial blood } \\
\text { pressure, cardiac } \\
\text { output, and } \\
\text { systemic vascular } \\
\text { resistance values } \\
\text { were monitored }\end{array}$ & Not specified & $\begin{array}{l}\text { Reduction in mortality in } \\
\text { single- and double-organ } \\
\text { failure in 28\% of septic } \\
\text { patients with combined } \\
\text { extracorporeal } \\
\text { detoxification }\end{array}$ \\
\hline $\begin{array}{l}\text { Hjorth V. } \\
\text { et al., 2000 [3] }\end{array}$ & $\begin{array}{l}\text { Retrospective } \\
\text { study }\end{array}$ & $\begin{array}{l}\text { Survival of the } \\
\text { patients }\end{array}$ & Not specified & Non conclusive \\
\hline
\end{tabular}

Our study is different in many aspects, as our study is prospective. In addition, time of TPE is fixed in all patients and heterogeneity is absent in the studied populations. We focus on septic shock patients in contrast to others who enrolled severe sepsis patients, and we focus on hemodynamic parameters.

However, as any research, the limitations of this study are the small sample size and the lack of a control group; therefore, future studies are needed in order to confirm the possible effect of early TPE.

\section{CONCLUSION}

Early initiation of TPE in severe septic shock patients might be beneficial regarding hemodynamics.

Introducere. Intervenția rapidă pentru şocul septic este crucială pentru a reduce mortalitatea şi a îmbunătăți prognosticul. Încă nu este clar momentul în care trebuie inițiată plasmafereza (TPE) la pacienții cu şoc septic. Studiul îş̧i propune să investigheze efectul inițierii rapide (primele patru ore) a plasmaferezei la aceşti pacienți.

Materiale şi metode. A fost realizat un studiu prospectiv de tip înainte-după pe 16 pacienți cu şoc septic internați în două secții de terapie intensivă din Cairo. Toți pacienții au primit plasmafereza în primele 4 ore de la internare.

Rezultate. Presiunea arterială medie s-a îmbunătățit după prima plasmafereză $(p<0,002)$. S-a observat o reducere a balanței nete hidroelectrolitice după prima plasmafereză cu o medie de $757 \mathrm{ml}(p<0,03)$. Rezistența vasculară periferică a fost îmbunătățită post-TPE cu o ameliorare a debitului cardiac $(p<0,01)$. Nivelurile proteinei $C$ reactive au fost semnificativ statistic imbunătățite dupa TPE $(p<0,01)$.

Concluzii. Inițierea precoce a TPE la pacienții cu şoc septic sever ar putea îmbunătăți parametrii hemodinamici.

Correspondence to: Rabab Mahmoud Ahmed, MD, Department of Internal Medicine, Faculty of Medicine, Cairo University, Cairo, Egypt.

E-mail: ruby_mahmoud_555@yahoo.com,rababmahmoud966@gmail.com

Conflict of interest disclosure: The authors declare there is no conflict of interest.

Acknowledgements: None.

\section{REFERENCES}

1. CARCILLO J.A., KELLUM J.A., Is there a role for plasmapheresis/plasma exchange therapy in septic shock, MODS, and thrombocytopenia-associated multiple organ failure? We still do not know - but perhaps we are closer, Intensive Care. Med., 2002, Oct., 28: 1373-5. 
2. RHODES A., EVANS L.E., ALHAZZANI W., LEVY M.M., ANTONELLI M., FERRER R. et al., Surviving Sepsis Campaign: International Guidelines for Management of Sepsis and Septic Shock: 2016, Intensive Care. Med., 2017, Mar., 43(3): $304-377$.

3. HJORTH V., STENLUND G., Plasmapheresis as part of the treatment for septic shock, Scand. J. Infect. Dis., 2000, 32: 511-4.

4. SCHMIDT J., MANN S., MOHR V.D., LAMPERT R., FIRLA U., ZIRNGIBL H., Plasmapheresis combined with continuous venovenous hemofiltration in surgical patients with sepsis, Intensive Care. Med., 2000, 26: 532-7.

5. RONCO C., BRENDOLAN A., LONNEMANN G., BELLOMO R., PICCINNI P., DIGITO A., A pilot study of coupled plasma filtration with adsorption in septic shock, Crit. Care. Med., 2002, 30: 1250-1255.

6. BUSUND R., KOUKLINE V., UTROBIN U., NEDASHKOVSKY E., Plasmapheresis in severe sepsis and septic shock: a prospective, randomised, controlled trial, Intensive Care. Med., 2002, Oct., 28: 1434-9.

7. ATAMAN K., JEHMLICH M., KOCK S., NEUMANN S., LEISCHIK M., FILIPOVIC Z., HOPF H.B., Short-term cardiovascular effects of plasmapheresis in norepinephrine-refractory septic shock, Intensive Care. Med., 2002, 28: 1164-1167.

8. STEGMAYR B.G., BANGA R., BERGGREN L., NORDA R., RYDVALL A., VIKERFORS T., Plasma exchange as rescue therapy in multiple organ failure including acute renal failure, Crit. Care. Med., 2003, Jun., 31: 1730-6.

9. JOHANNES HADEM, CARSTEN HAFER, ANDREA S. SCHNEIDER, OLAF WIESNER, GERNOT BEUTEL, THOMAS FUEHNER, TOBIAS WELTE, MARIUS M. HOEPER et al., Therapeutic plasma exchange as rescue therapy in severe sepsis and septic shock: retrospective observational single-centre study of 23 patients, BMC Anesthesiol., 2014, 14: 24.

10. SCHOENBERG M.H., WEISS M., RADERMACHER P., Outcome of patients with sepsis and septic shock after ICU treatment, Langenbecks Arch. Surg., 1998, Mar., 383: 44-8.

11. LEVY M.M., DELLINGER R.P., TOWNSEND S.R. et al., Surviving Sepsis Campaign. The Surviving Sepsis Campaign: Results of an international guideline-based performance improvement program targeting severe sepsis, Crit. Care. Med., 2010, 38: $367-374$.

12. LEVY M.M., RHODES A., PHILLIPS G.S. et al., Surviving Sepsis Campaign: Association between performance metrics and outcomes in a 7.5-year study, Crit. Care. Med., 2015, 43: 3-12.

13. LEVY M.M., PRONOVOST P.J., DELLINGER R.P. et al., Sepsis change bundles: Converting guidelines into meaningful change in behavior and clinical outcome, Crit. Care. Med., 2004, 32: S595-S597.

14. DAMIANI E., DONATI A., SERAFINI G. et al., Effect of performance improvement programs on compliance with sepsis bundles and mortality: A systematic review and meta-analysis of observational studies, PLoS One, 2015, 10: 0125827.

15. RHODES A., PHILliPS G., BEALE R. et al., The Surviving Sepsis Campaign bundles and outcome: Results from the International Multicentre Prevalence Study on Sepsis (the IMPreSS study), Intensive Care. Med., 2015, 41: 1620-1628.

16. DWYER J., One Boy's Death Moves State to Action to Prevent Others, 2012, Available at: http://www.nytimes.com/2012/12/21/ nyregion/one-boys-death-moves-state-to-action-to-prevent-others.html, Accessed December 27, 2017.

17. SEYMOUR C.W., GESTEN F., PRESCOTT H. et al., Time to treatment and mortality during mandated emergency care for sepsis, N. Engl. J. Med., 2017, 376: 2235-2244.

18. LIU V.X., MOREHOUSE J.W., MARELICH G.P. et al., Multicenter implementation of a treatment bundle for patients with sepsis and intermediate lactate values, Am. J. Respir. Crit. Care. Med., 2016, 193: 1264-1270.

19. LEISMAN D.E., DOERFLER M.E., WARD M.F. et al., Survival benefit and cost savings from compliance with a simplified 3-hour sepsis bundle in a series of prospective, multisite, observational cohorts, Crit. Care. Med., 2017, 45: 395-406.

20. FERRER R., MARTIN-LOECHES I., PHILLIPS G. et al., Empiric antibiotic treatment reduces mortality in severe sepsis and septic shock from the first hour: Results from a guideline-based performance improvement program, Crit. Care. Med., 2014, 42: 1749-1755.

21. KUMAR A., ROBERTS D., WOOD K.E. et al., Duration of hypotension before initiation of effective antimicrobial therapy is the critical determinant of survival in human septic shock, Crit. Care. Med., 2006, 34: 1589-1596.

22. KUMAR A., Systematic bias in meta-analyses of time to antimicrobial in sepsis studies, Crit. Care. Med., 2016, 44: e234-e235.

23. SEYMOUR C.W., LIU V.X., IWASHYNA T.J. et al., Assessment of clinical criteria for sepsis: for the Third International Consensus Definitions for Sepsis and Septic Shock (Sepsis-3), JAMA, 2016, 315: 762-774.

24. HOEPER M.M., ABOU-REBYEH F., ATHMAN C., SCHWARZ A., Plasmapheresis in streptococcal toxic shock syndrome, Crit. Care. Med., 2001, 29: 2399.

Received September $28^{\text {th }} 2019$ 